\title{
The Cape Town Statement on Geoethics
}

\author{
GIUSEPPE Di CAPUA, SILVIA PEPPOLONI \\ Istitu to Nazionale di Geofisica e Vulcanologia, Italy \\ IAPG - International Association for Promoting Geoethics \\ giuseppe.dicapua@ingv.it, silvia.peppoloni@ingv.it \\ PETER T. BOBROWSKY \\ Geological Survey of Canada - Natural Resources Canada \\ IAPG - International Association for Promoting Geoethics \\ Peter.Bobrowsky@canada.ca
}

\begin{abstract}
Recently the interest by geoscientists in (geo)ethical aspects of geoscience knowledge, education, research, practice and communication has grown considerably. Today the topic of geoethics has gained a significant visibility within the scientific community. The IA PG - International A ssociation for Promoting Geoethics (http://www.geoethics.org), founded in 2012, has worked to widen the discussion and create awareness about issues of ethics as applied to the geosciences. Thanks to continuous voluntary work, the respectful exchange, and fruitful sharing of ideas, the IA PG community has produced a conceptual substratum on which to base the future development of geoethics, by clarifying the meaning of the word "geoethics", formalizing its definition, and better identifying a framework of reference values on which the geoscience community can base more effective codes of conduct and guidance. The members of the IA PG community have published various books and articles in peer-reviewed international journals, and organized numerous scientific sessions to bring geoethics to the most important geoscience conferences. Geoethical issues have been also included in the European project ENVRI-Plus, which is dedicated to the environmental and solid Earth research infrastructures. The tan gible result of these efforts is that, now, many prestigious geoscience organizations recognize geoethics as a fundamental issue, worthy of attention. This result was confirmed by the high quality of content and the large participation of scientists in the six technical sessions and a panel session on geoethics organized by IA PG at the 35th IGC-International Geological Congress, held in 2016 in Cape Town (South Africa). Largely successful due to the cooperative work of different geoscience organizations (IUGS-TGGP - Task Group on Global Geoscience Professionalism; GSL - Geological Society of London; EFG - European Federation of Geologists; EGS - EuroGeoSurveys; A GI - American Geosciences Institute; AGU American Geophysical Union, and AAWG - African Association of Women in Geosciences). The IA PG considers the 35th IGC as the scientific event that opened a new phase for furthering the concept of geoethics. In order to mark this milestone, the "Cape Town Statement on Geoethics" (CTSG) was tabled by the IA PG and reviewed in an international effort. It shall focus the attention of geoscientists on the development of shared values, policies, guidelines, strategies and tools, with the long-range goal of fostering the regular adoption of ethical values and practices within the geoscience community. The document summarizes the values, concepts, and contents developed by IAPG so far, providing a perspective for the future development of geoethical thinking. This paper addresses in detail the content of the "Cape Town Statement on Geoethics", which is now supported officially by several geoscience organizations.
\end{abstract}

\section{INTRODUCTION}

$\mathrm{I}$ n recent years, the geoscience community has shown a growing interest for geoethics. The work carried out by the IAPG in its first five years of activity has brought forward tan- gible results. They have facilitated the growth of this emerging field of scholarly inquiry. This includes the publication of numerous books and articles written under a peer-review process (Lollino et al., 2014; Peppoloni and Di Capua, 2012 and 2015; Peppoloni et al., 2017; Wyss 
and Peppoloni, 2014) and more than 70 events (scientific sessions, conferences, workshops, seminars, etc.) that have been organized worldwide (http:/ / www.geoethics.org/ events, accessed 30 October 2017. The consequence is that more geoscientists are now discussing the ethical and social implications of their work (Mansur et al., 2017; Meller et al., 2017; Stew art and Gill, 2017; Stew art and Lewis, 2017; Vasconcelos et al., 2016) and recognize geoethics as a transversal subject in geosciences (Bobrow sky et al., 2017). Thanks to the involvement of many geoscientists, it has been possible to provide geoethics with a more solid conceptual substratum (for a summary see Peppoloni and Di Capua, 2014 and 2017; Bobrow sky et al., 2017). Starting from the etymological analysis of the words "geo" and "ethics", a definition of geoethics has been elaborated, several geoscience issues upon which geoethics can apply its analyses have been identified, and a set of geoethical values have been proposed. The latter offer a sort of common ground of reasoning to be used by geoscientists coming from various countries, having often huge differences in their cultural experiences, views and economic perspectives, although needing to share a common geoscience vision. After years of activity, we are now able to trace a coherent path in the theoretical and practical development of geoethics that can strengthen its credibility in the geoscience community.

The Cape Town Statement on Geoethics (CTSG), released officially on October 2016, is a document that defines a conceptual framew ork for the study of geoethics, and provides a first step to start to explore whether geoethics could evolve into a new discipline, either within geosciences or within ethical sciences.

\section{THE CONTEXT}

The CTSG was prepared during the 35th International Geological Congress, held in Cape Town (South Africa) in August-September 2016, where IAPG organized six technical sessions and a panel session on geoethics, with a large number of speakers and a diverse and active audience (http:/ / www.geoethics.org/ 35th-igc, accessed 30 October 2017). The document is the product of an international effort, the result of a coopera- tive work that has involved geoscientists from all over the world during the period 2012 to 2016. The CTSG's aim is to focus the attention of geoscientists on the development of shared policies, guidelines, strategies and tools, with the long-range goal of fostering the widespread adoption of ethical practices in the geoscience community. Discussions during scientific meetings, editorial projects and other activities carried out under the umbrella of IAPG have provided the fertile ground to circulate ideas and to make more colleagues aware about the necessity to give geoethics a coherent theoretical framew ork structure.

\section{WHY THIS DOCUMENT WAS NECESSARY}

Ethical and social implications in geoscience research and practice are becoming key-aspects in the geoscience profession. Geoethics sharpen categories to face the many issues that involve both the scientific communities and societies: intellectual freedom and honesty, responsibility, respect, prevention, adaptation, and sustainability (Peppoloni et al., 2015; Peppoloni and Di Capua, 2016). In order to frame the geoethics discussion, it was important to fix several essential results coming from a cooperative effort in renewed thinking about geoscience's role in itself and for society. The prestigious International Geological Congress (IGC), that since 1878 has attracted geoscientists from all over the world, seemed the best event to launch a statement on geoethics as a product of a scientific community with a high level technical-scientific knowledge, but now more aw are also of its ethical and social responsibility in practicing geosciences.

Since the 34th International Geological Congress, geoethics has reached a much higher level of visibility and standing. Moreover, the common space of a broad international network of colleagues and organizations involved in the discussion on geoethical issues and the high quality contents in books and articles urged to propose a summary document, which gives to the geoscience community a framework of reference on geoethics, outlines achievements, and orientates the future development of the ethical and social discussion. 


\section{THE CTSG STRUCTURE}

The CTSG is structured into several sections (see Appendix A). The "Preamble" clearly indicates the overarching objective of the entire document. The "Introduction" outlines both, the context in which geoscientists are now operating, and the premises for following a geoethical approach. The section "Definition of Geoethics" details the IAPG formula (originally a contribution in Wyss and Peppoloni, 2014). The formula is based on the term "ethics" as introduced by Aristotle (384-322 BC), and was defined with the involvement of sociologists and philosophers. The section "Purpose" delineates the scope of geoethics, why it is essential for the geoscience community and society. The purpose to embrace geoethics is to improve the quality of research and professional work and the credibility of geoscientists, foster excellence in geosciences, guarantee sustainable benefits for communities, protect local and global environments, and ensure the conditions for a healthy and prosperous development of future generations. In the section "Fundamental Values of Geoethics" the CTSG lists values to be considered for an ethical approach to technical and scientific problems related to geosciences. They regard both the individual and the social sphere of geoscientists, in particular the four dimensions to consider in geoethical analysis (self, colleagues, society, and environment). The keyw ord is "responsibility", one that should become the foundation of any action of geoscientists, in all the different fields of their activities (e.g. professional, academic and research fields, education activity, public employment, industry) (Peppoloni and Di Capua, 2016). The section "Geoethical Promise" contains a slightly revised version of the Geoethical Promise, an Hippocratic-like oath for geoscientists, originally proposed by Matteucci et al. (2014). The Geoethical Promise is one w ay to emphasize the values that young scientists must keep in mind during their geoscience career. It is also a tool for senior geoscientists to re-consider ideals that direct their activities. The section "Final Statement" closes the document, underlying future environmental and social challenges, encouraging geoscientists to raise their responsibility, and strengthen the credibility of geosciences in order to secure societal trust. The final statement stresses the necessity of the document for the geoscience community in the light of global challenges (energy, water, minerals, georisks, pollution, land degradation) that geoscientists face by society.

The final version of the CTSG, improved with comments and suggestions of reviewers, was presented at the 35th IGC on 29 August 2016, discussed at the 1st IAPG General Assembly in Cape Town on 31st August 2016, then ratified by the IAPG Executive Council on 26th October 2016 and released officially in the IAPG website.

The CTSG is a reference document and it is supported by 18 geoscience organizations thus far (http:// www.geoethics.org/ ctsg, accessed 30 October 2017). In order to increase its global impact, the statement will be translated into several languages, thanks to the cooperation of dozens of colleagues, as already done for the Montreal Statement on Research Integrity (Peppoloni, 2015). Providing access in a number of languages means we can enhance the cultural diversity as an element of union, through which all scientists can share universal values and strengthen their common identity in social diversity.

\section{CONCLUSION}

The CTSG shall encourage a more responsible behaviour of practice in geosciences. It addresses firstly the geoscience community, but has important significance also to society as a whole, as it synthesizes some values that must guide human actions with respect to the Earth system. Through the CTSG several important matters have been recommended that may encourage colleagues to further their ethical and social role, to dutifully foster excellent science and a professional service to the society.

Many colleagues promote a responsible way to approach problems involving geoscience knowledge and to find reasonable solutions, based on acceptable compromises if needed. Re-discovering also an ideal dimension in the geoscience profession means to work more effectively for the common good, going so beyond the simple personal success. 


\section{REFERENCES}

Bobrow sky P., Cronin V.S., Di Capua G., Kieffer S.W., Peppoloni S. (2017). The Emerging Field of Geoethics. In: Scientific Integrity and Ethics with Applications to the Geosciences, edited by L.C. Gundersen. Special Publication American Geophysical Union, John Wiley and Sons, Inc.

Lollino G., Arattano M., Giardino M., Oliveira R., Peppoloni S. (2014). Engineering Geology for Society and Territory - Volume 7 "Education, Professional Ethics and Public Recognition of Engineering Geology", XVII, 274 p., Springer, ISBN: 978-3319093024.

Mansur K.L., Ponciano L.C.M.O., De Castro A.R.S.F. (2017). Contributions to a Brazilian Code of Conduct for Fieldw ork in Geology: an approach based on Geoconservation and Geoethics. Anais da Academia Brasileira de Ciências (Annals of the Brazilian Academy of Sciences), vol. 89, no. 1, supl. 0, 431-444.

Matteucci R., Gosso G., Peppoloni S., Piacente S., Wasowski J. (2014). The "Geoethical Promise": A Proposal. Episodes, Vol. 37, no. 3, pp. 190-191.

Meller C., Schill E., Bremer J., Kolditz O., Bleicher A., Benighaus C., Chavot P., Gross M., Pellizzone A., Renn O., Schilling F., Kohl T. (2017). Acceptability of geothermal installations: A geoethical concept for GeoLaB. Geoethermics, Available online $14 \quad$ August 2017: http:/ / www.sciencedirect.com/ science/ article / pii/ S0375650517300858, accessed 4 October 2017.

Peppoloni S. (2015). Sharing ethical principles through cultural diversity. Translations of the Montreal Statement on Research Integrity in Cross Boundary Research Collaborations. IAPG - International Association for Promoting Geoethics: http:/ / www geoethics.org/ translationsms, accessed 30 October 2017.

Peppoloni S., Bobrowsky P., Di Capua G. (2015). Geoethics: A Challenge for Research Integrity in Geosciences, pp. 287-294, doi: 10.1142/ 9789814632393_0035. In: Steneck N., Anderson M., Kleinert S., Mayer T. (Eds.), Integrity in the Global Research Arena, 336 pp., World Scientific Publishing Co, ISBN: 9789814632386.

Peppoloni S. and Di Capua G. (2012). Geoethics and geological culture - Reflections from the Geoitalia Conference 2011. Annals of Geophys- ics, Vol. 55, No 3, p.163: http:/ / www.annalsofgeophysics.eu/ index.php / annals/ issue/ view/482, accessed 30 October 2017.

Peppoloni S. and Di Capua G. (2014). The Meaning of Geoethics. In: Wyss M. and Peppoloni S. (Eds), Geoethics: ethical challenges and case studies in Earth Science, 450 p., Elsevier, Waltham, Massachu setts, ISBN: 9780127999357.

Peppoloni S. and Di Capua G. (2015). Geoethics: the Role and Responsibility of Geoscientists. Geological Society, London, Special Publications, 419, ISBN: 9781862397262.

Peppoloni S. and Di Capua, G. (2016). Geoethics: Ethical, social, and cultural values in geosciences research, practice, and education, pp. 17-21, doi: 10.1130/ 2016.2520(03). In: Wessel G.R. and Greenberg J.K. (Eds), Geoscience for the Public Good and Global Development: Tow ard a Su stainable Future: Geological Society of America Special Paper 520, 2016, ISBN: 9780813725208.

Peppoloni S. and Di Capua G. (2017). Geoethics: ethical, social and cultural implications in geosciences. Annals of Geophysics, 60, Fast Track 7, doi: 10.4401/ ag-7473.

Peppoloni S., Di Capua G., Bobrow sky P.T., Cronin V. (2017). Geoethics at the heart of all geoscience. Annals of Geophysics, Vol 60, Fast Track 7: http:/ / www.annalsofgeophysics.eu/ index.php / annals/ issue/ view/ 537, accessed 30 October 2017.

Stew art I.S. and Gill J.C. (2017). Social geology integrating sustainability concepts into Earth sciences. Proceeding of the Geologists' Association, Volume 128, Issue 2, Pages 165-172.

Stewart I.S. and Lew is D. (2017). Communicating contested geoscience to the public: Moving from 'matters of fact' to 'matters of concern'. Earth-Science Reviews, Volume 174, Pages 122-133.

Vasconcelos C., Torres J., Vasconcelos L., Moutinho S. (2016). Sustainable Development and its Connection to Teaching Geoethics. Episodes, vol. 39, n. 3, pp. 509-517.

Wyss M. and Peppoloni S. (2014). Geoethics, Ethical Challenges and Case Studies in Earth Sciences. p. 450, Elsevier, ISBN: 9780127999357. 


\section{APPENDIX A \\ THE CAPE TOWN STATEMENT ON GEOETHICS}

\section{Preamble}

The concepts, values and views on individual responsibilities of geoscientists, expressed in the "Cape Town Statement on Geoethics" reflect an international consensus. The statement aims to capture the attention of geoscientists and organizations, and to stimulate them to improve their shared policies, guidelines, strategies and tools to ensure they consciously embrace (geo)ethical professional conduct in their work.

\section{Introduction}

Geosciences have major impacts on the functioning and knowledge-base of modern societies. Geoscientists have specific knowledge and skills, which are required to investigate, manage and intervene in various components of the Earth system to support human life and wellbeing, to defend people against geohazards and to ensure natural resources are managed and used sustainably. This entails ethical obligations. Therefore, geoscientists must embrace ethical values in order best to serve the public good.

Geoethics is an emerging subject, which promotes a way of thinking and practicing geosciences, within the wider context of the roles of geoscientists interacting with colleagues, society and the planet.

Only by guaranteeing the intellectual freedom of researchers and practitioners to explore and discover in the Earth system, is it possible for geoscientists to follow ethical approaches in their work. Likewise, only by increasing researchers' and practitioners' awareness of the ethical implications of their work is it possible to develop excellent geoscience to serve society and to reduce the human impact on the environment.

\section{Definition of Geoethics}

Geoethics consists of research and reflection on the values which underpin appropriate behaviours and practices, wherever human activities interact with the Earth system.
Geoethics deals with the ethical, social and cultural implications of geosciences knowledge, education, research, practice and communication, and with the social role and responsibility of geoscientists in conducting their activities.

\section{Purpose}

Embracing geoethics is essential: to improve both the quality of professional work and the credibility of geoscientists, to foster excellence in geosciences, to assure sustainable benefits for communities, as well as to protect local and global environments; all with the aim of creating and maintaining the conditions for the healthy and prosperous development of future generations.

\section{Fundamental Values of Geoethics}

- Honesty, integrity, transparency and reliability of the geoscientist, including strict adherence to scientific methods;

- Competence, including regular training and life-long learning;

- Sharing knowledge at all levels as a valuable activity, which implies communicating science and results, while taking into account intrinsic limitations such as probabilities and uncertainties;

- Verifying the sources of information and data, and applying objective, unbiased peer-review processes to technical and scientific publications;

- Working with a spirit of cooperation and reciprocity, which involves understanding and respect for different ideas and hypotheses;

- Respecting natural processes and phenomena, where possible, when planning and implementing interventions in the environment;

- Protecting geodiversity as an essential aspect of the development of life and biodiversity, cultural and social diversity, and the sustainable development of communities;

- Enhancing geoheritage, which brings together scientific and cultural factors that have intrinsic social and economic value, to strengthen the sense of belonging of people for their environment; 
- Ensuring sustainability of economic and social activities in order to assure future generations' supply of energy and other natural resources.

- Promoting geo-education and outreach for all, to further sustainable economic development, geohazard prevention and mitigation, environmental protection, and increased societal resilience and well-being.

\section{Geoethical Promise}

The adoption of the following Hippocratic-like oath (the "Geoethical Promise") by early-career geoscientists is proposed, to promote respect for geoethics values in geoscience research and practice:

I promise...

... I will practice geosciences being fully aware of the societal implications, and I will do my best for the protection of the Earth system for the benefit of humankind.

... I understand my responsibilities towards society, future generations and the Earth for sustainable development.

... I will put the interest of society foremost in my work.

... I will never misuse my geoscience knowledge, resisting constraint or coercion.

... I will always be ready to provide my professional assistance when needed, and will be impartial in making my expertise available to decision makers.

... I will continue lifelong development of my geoscientific knowledge.

... I will always maintain intellectual honesty in my work, being aware of the limits of my competencies and skills.

... I will act to foster progress in the geosciences, the sharing of geoscientific knowledge, and the dissemination of the geoethical approach.

... I will always be fully respectful of Earth processes in my work as a geoscientist.

I promise!

\section{Final Statement}

It is essential to enrich the roles and responsibilities of geoscientists towards communities and the environments in which they dwell, as well as paying attention to each scientist's individual conscience and relationships with colleagues. Human communities will face great environmental challenges in the future. Geoscientists have know-how that is essential to orientate societies tow ards more sustainable practices in our conscious interactions with the Earth system. Applying a wider knowledgebase than natural sciences, geoscientists need to take multidisciplinary approaches to economic and environmental problems, embracing (geo)ethical and social perspectives. Geoscientists are primarily at the service of society. This is the deeper purpose of their activity.

In the coming years, especially when addressing matters like energy supply, use of georesources, land management, pollution abatement, mitigation of geo-risks, and climate change adaptation and mitigation, ethical and social issues will be central in scientific discussion and in public debate. In addition, handling large quantities of data, science and risk communication, education strategies, issues of research integrity, anti-harassment and antidiscrimination policies, gender balance and inclusion of those living with disabilities will be major topics for geoscientists.

Raising the (geo)ethical aw areness and competences of the members of the geoscience community is essential, also to increase trust and credibility among the public. This can best be achieved in the near future by two means: by promoting more effectively existing guidance such as codes of ethics/ conduct and research integrity statements; and by introducing geoethics into geoscience curricula, to make geoethics a basic feature of the training and professional activity of geoscientists.

Note:

The Cape Town Statement on Geoethics was prepared during the 35th IGC - International Geological Congress in Cape Town, South Africa (27 August - 4 September 2016). Drafting Committee: Giuseppe Di Capua, Silvia Peppoloni, Peter T. Bobrowsky. With the contribution of: Nic Bilham, Martin Bohle, Andy Clay, Emilia Hermelinda Lopera-Parejas, David Mogk. Approved by the IAPG Executive Council on 26 October 2016. Website: http://www.geoethics.org/ctsg 